Medical Principles and Practice

Alexander Voevodin ${ }^{\text {a }}$

Elena Samilchuk ${ }^{\mathrm{b}}$

Suhaila Dashti ${ }^{\mathrm{a}}$

a Department of Microbiology,

Faculty of Medicine,

Kuwait University, and

b Kuwait Medical Genetics Centre,

Ministry of Health, Kuwait

\section{Key Words}

HIV-1

CCR-5

$\Delta \mathrm{ccr}-5$

Polymerase chain reaction

Genetic resistance

Allele frequency

\title{
The $\Delta$ ccr-5 Mutation in the CCR-5 Chemokine Receptor Gene Conferring Resistance to Human Immunodeficiency Virus Type 1: Frequency in Kuwait
}

\begin{abstract}
Objective: The homozygous deletion of 32 nucleotides in the CCR-5 gene $(\Delta \mathrm{ccr}-5)$ confers resistance to macrophage-tropic HIV-1. The aim of this study was to determine the frequency of $\Delta \mathrm{ccr}-5$ in populations residing in Kuwait. Methods: A polymerase chain reaction (PCR) test for $\Delta \mathrm{ccr}-5$ has been developed. The specificity of the test has been proved by direct sequencing of the PCR products amplified from individuals homozygous for the wild-type allele and from $\Delta$ ccr-5/wild-type heterozygotes. Results: Among 353 healthy individuals residing in Kuwait (270 Kuwaiti citizens and 83 Bedouins) tested for the $\Delta$ ccr- 5 mutation, 8 heterozygotes have been identified, 4 in each group. No homozygotes for the $\Delta \mathrm{ccr}-5$ deletion have been found. The frequency of the $\Delta$ ccr- 5 allele in Kuwaiti nationals and Bedouins residing in Kuwait is 0.74 and 2.4\%, respectively. Conclusion: The $\Delta \mathrm{ccr}-5$ mutation is present in populations residing in Kuwait, though its frequency is quite low and can hardly influence the pace of HIV-1 spreading in Kuwait.
\end{abstract}

\section{Introduction}

One of the most challenging and intriguing observations in the HIV/AIDS field is the existence of individuals remaining HIV-free, despite repeated exposure to the virus through sexual contacts $[1,2]$. Such 'exposed-uninfected' individuals are 'naturally resistant' to HIV infection. Such resistance has been considered to be genetic, but until recently proofs have been lacking.

\begin{tabular}{ll}
\hline KARGER & ( 1998 S. Karger AG, Basel \\
Fax +41 61 306 12 34 & 1011-7571/98/0074-0271\$15.00/0 \\
$\begin{array}{l}\text { E-Mail karger@karger.ch } \\
\text { www.karger.com }\end{array}$ & $\begin{array}{l}\text { Accessible online at: } \\
\text { http://BioMedNet.com/karger }\end{array}$
\end{tabular}

Dr. Alexander Voevodin
Department of Microbiology
Faculty of Medicine, Kuwait University
PO Box 24923, 13110 Safat (Kuwait)
Tel./Fax+965 2663598, E-Mail voevodin@hsc.kuniv.edu.kw 
In 1996, after a decade of unsuccessful attempts, the 'second HIV receptor' (also called 'coreceptor') was identified for both $\mathrm{T}$ cell line (T)-tropic and macrophage (M)-tropic strains of HIV-1. Both coreceptors turned out to be members of the seven-transmembrane domain, G-protein-coupled chemokine receptor family. The CXCR-4 chemokine (also known as fusin or LESTR) serves as the coreceptor for T-tropic HIV-1, while the CCR-5 chemokine (also known as C-C CKR5) does the same for M-tropic HIV-1 [3-8].

The relevance of the HIV coreceptor to the problem of natural resistance to HIV-1 infection and AIDS became apparent when identical homozygous mutations were found in some 'HIV-1 exposed-uninfected' individuals [9]. The mutation (a 32-nucleotide deletion in the CCR-5 gene, called $\Delta$ ccr-5) results in truncation of the CCR-5 protein. The truncated CCR5 fails to mediate chemokine signaling and to facilitate entry of HIV-1 into the macrophagic target cells. As a result, the cells bearing the mutation become resistant to HIV-1. Individuals carrying $\Delta \mathrm{ccr}-5$ in the homozygous state are highly resistant to HIV-1 infection, though the resistance is not absolute $[10,11]$.

Unexpectedly, the $\Delta \mathrm{ccr}-5$ mutation has been found to be quite common among individuals of West European descent (mutant allele frequency 0.080-0.092). At the same time, the mutation has not been found in individuals of African, South American and Japanese origin $[9,10]$. The frequency of $\Delta$ ccr- 5 in other ethnic groups was unknown at the beginning of this study.

In this paper, we present the first data on the frequency of the $\Delta c c r-5$ mutation in an Arab population. The preliminary report of our study was presented at the 5th Kuwait International Conference on AIDS, March 17-19, 1997 [12] and at the Kuwait University Faculty of Medicine Poster Day, April 2930, 1997 [13].

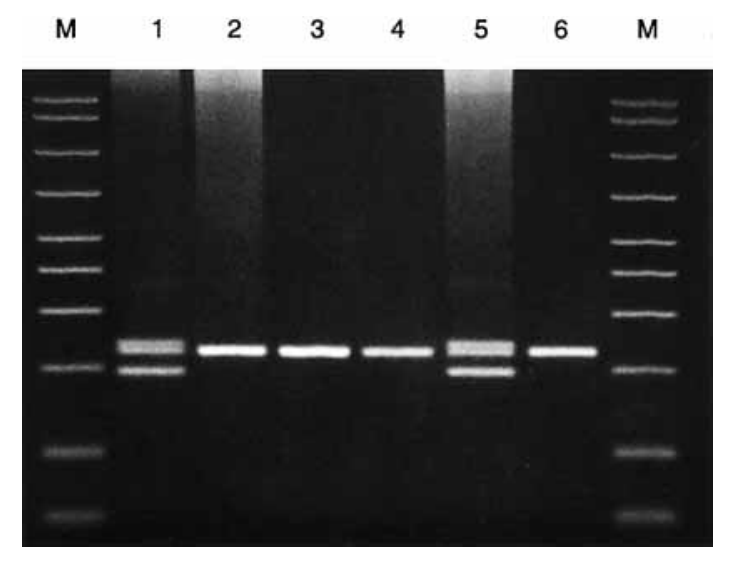

Fig. 1. Typical results of identification of $w / w$ and $\Delta$ ccr-5/w genotypes by PCR. $\mathrm{M}=$ Markers $(50,100$, 200, 300, 400, 500, 700, 1,000, 1,500 and 2,000 bp); lanes $1,5=\Delta \mathrm{ccr}-5 / \mathrm{w}$ heterozygotes (wild-type allele band $230 \mathrm{bp}, \Delta \mathrm{ccr}-5$ allele band $198 \mathrm{bp}$, the band above the $230 \mathrm{bp}$ consists of heteroduplexes); lanes 2 , $3,4,6=$ wild-type homozygotes.

\section{Materials and Methods}

\section{DNA Samples}

Whole blood samples from 353 individuals (270 Kuwaiti citizens and 83 Bedouins residing in Kuwait) were collected and used for extraction of DNA. The DNA was extracted from leukocytes using the Chelex 100 method [14]. The study group included voluntary blood donors and healthy relatives of the individuals referred to the Kuwait Medical Genetics Centre.

Polymerase Chain Reaction for Detection of the $\Delta c c r-5$

The primers AV-66 (5'-CTGTGTTTGCGTCTCTCC-3') and AV-67 (5'-CCTGTGCCTCTTCTTCTCA-3') were used to amplify the 230-bp fragment of the CCR-5 gene containing the site of mutation. The reaction mixture included standard polymerase chain reaction (PCR) buffer $(10 \mathrm{~m} M$ Tris- $\mathrm{HCl}, \mathrm{pH} 8.3$, $50 \mathrm{~m} M \mathrm{KCl}, 1.5 \mathrm{mM} \mathrm{Mg} 2 \mathrm{Cl}), 50 \mu M$ of deoxynucleoside triphosphates, $10 \mathrm{pmol}$ of each primer and $5 \mu \mathrm{l}$ of Chelex-100-extracted DNA from leukocytes in a total volume of $25 \mu 1$. Thermocycling $\left(94,55\right.$ and $72{ }^{\circ} \mathrm{C}$, $30 \mathrm{~s}$ at each temperature, 30 cycles) was performed in a Perkin-Elmer system 9600. Standard precautions to prevent carry-over artifacts were strictly followed [15]. 


\begin{tabular}{|c|c|c|c|c|c|c|}
\hline & & 10 & 20 & 30 & 40 & 50 \\
\hline CCR5-X91492 & 1 & CAGGAATCAT & CTTTACCAGA & TCTCAAAAAG & AAGGTCTTCA & TTACACCTGC \\
\hline$C C R-5-W / W$ & 1 & CAGGAATCAT & CTTTACCAGA & TCTCAAAAAG & AAGGTCTTCA & TTACACCTGC \\
\hline \multirow[t]{2}{*}{$C C R-5-\Delta / \Delta$} & 1 & CAGGAATCAT & CTTTACCAGA & TCTCAAAAAG & AAGGTCTTCA & TTACACCTGC \\
\hline & & 60 & 70 & 80 & 90 & 100 \\
\hline CCR5-X91492 & 51 & AGCTCTCATT & TTCCATACAG & TCAGTATCAA & TTCTGGAAGA & ATTTCCAGAC \\
\hline$C C R-5-W / W$ & 51 & AGCTCTCATT & TTCCATACAG & TCAGTATCAA & TTCTGGAAGA & ATTTCCAGAC \\
\hline \multirow[t]{2}{*}{$\operatorname{CCR}-5-\Delta / \Delta$} & 51 & AGCTCTCATT & TTCCATACA- & ---------- & ---------- & --------- \\
\hline & & 110 & 120 & 130 & 140 & 150 \\
\hline CCR5-X91492 & 101 & ATTAAAGATA & GTCATCTTGG & GGCTGGTCCT & GCCGCTGCTT & GTCATGGTCA \\
\hline$C C R-5-W / W$ & 101 & ATTAAAGATA & GTCATCTTGG & GGCTGGTCCT & GCCGCTGCTT & GICATGGICA. \\
\hline $\mathrm{CCR}-5-\Delta / \Delta$ & 101 & -TTAAAGATA & GTCATCTTGG & GGCTGGTCCT & GCCGCTGCTT & GTCATGGTCA \\
\hline
\end{tabular}

Fig. 2. DNA sequence comparison of the wild-type and $\Delta$ ccr- 5 alleles of the human CCR-5 gene. CCR5-X91492 = Prototype sequence of the human CCR-5 gene (GenBank Accession Number X91492); CCR-5-W/W = partial sequence of the wild-type allele of the human CCR-5 gene; CCR-5- $\Delta / \Delta=$ partial sequence of the $\Delta$ ccr-5 allele of the human CCR-5 gene.

The detection of the amplimers was carried out by minigel electrophoresis in $1.7 \%$ agarose (NA, Pharmacia, Uppsala, Sweden) and staining with ethidium bromide.

\section{DNA Sequencing and Analysis}

PCR-amplified fragments of the CCR-5 gene were sequenced directly using the AV-66/AV-67 primers according to the manufacturer's (Applied Biosystems/ Perkin Elmer, Foster City, Mich., USA) protocols using a Dye Terminator Cycle Sequencing Kit with AmpliTaq DNA Polymerase FS and the Applied Biosystems Model 373 automatic DNA sequencer. To minimize artifacts due to Taq polymerase mistakes, samples were prepared for sequencing as a pool of 10 separate PCR amplifications with the same target DNA and primers. The DNA sequences were aligned and compared with the help of the DNASIS program (Hitachi).

\section{Results}

Three possible outcomes were expected for the PCR amplification of the region of the human CCR-5 gene defined by selected primers: (1) a single 230-bp fragment in wild-type homozygotes (genotype w/w); (2) a single 198bp fragment in $\Delta \mathrm{ccr}-5$ homozygotes (genotype
$\Delta \mathrm{ccr}-5 / \Delta \mathrm{ccr}-5$ ), and (3) both the 230-bp and 198 -bp fragments in a $\Delta$ ccr-5/wild-type heterozygotes ( $\Delta$ ccr-5/w genotype).

In our set of samples, two of these patterns were observed: the pattern corresponding to $\mathrm{w} / \mathrm{w}$ and that corresponding to the $\Delta \mathrm{ccr}-5 / \mathrm{w}$ genotypes (fig. 1). The vast majority of the samples tested in this study (345) revealed the 230-bp band only (w/w genotype). In 8 cases, the pattern consistent with genotype $\Delta \mathrm{ccr}-5 / \mathrm{w}$ was observed. To confirm the specificity of the PCR conclusively, we sequenced part of the 230-bp fragment containing the region of the $\Delta \mathrm{ccr}-5$ deletion. The DNA sequence generated was identical to the prototype sequence of the corresponding fragment of the CCR-5 gene (fig. 2) $[10,16]$. Thus, the amplification of the single 230-bp band by our PCR indeed is diagnostic for the $\mathrm{w} / \mathrm{w}$ genotype. To prove conclusively that the 198-bp band in the heterozygous samples represents the $\Delta \mathrm{ccr}-5$ allele, we sequenced the part of the 198-bp fragment framing the deletion. This was achieved by reamplification of the fragment (recovered from the agarose after electrophoretic separation by pricking with a syringe needle) fol- 
Table 1. Frequency of the $\Delta c c r-5$ deletion in the Kuwaitis and the Bedouins residing in Kuwait (data from this study) and some other ethnic groups (reported by others)

\begin{tabular}{lrrrl}
\hline Group & $\begin{array}{l}\text { Sample } \\
\text { size }\end{array}$ & $\Delta \mathrm{ccr}-5 / \mathrm{w}, \mathrm{n}$ & $\mathrm{w} / \mathrm{w}, \mathrm{n}$ & $\begin{array}{l}\Delta \mathrm{ccr}-5 / \mathrm{w} \\
\text { allele } \\
\text { frequency }\end{array}$ \\
& & & & \\
\hline Kuwait & & & & \\
$\quad$ Kuwaitis & 270 & 4 & 266 & 0.007 \\
$\quad$ Bedouins & 83 & 4 & 79 & 0.024 \\
$\quad$ Total & 353 & 8 & 345 & 0.011 \\
\hline Saudi Arabia [18] & 241 & 10 & 231 & 0.020 \\
Yemen [18] & 34 & 0 & 34 & 0 \\
W. Europe [10] & 704 & 114 & 582 & $0.092^{1}$ \\
USA, white [17] & 143 & 23 & 120 & 0.080 \\
USA, black [17] & 620 & 21 & 599 & 0.017 \\
Africa [10] & 124 & 0 & 124 & 0 \\
Japan [10] & 248 & 0 & 248 & 0 \\
Venezuela [10] & 46 & 0 & 46 & 0 \\
\hline
\end{tabular}

1 Eight $\Delta \mathrm{ccr}-5 / \Delta \mathrm{ccr}-5$ homozygotes in this group. lowed by direct sequencing of the reamplified product. As expected, the sequence generated contained a 32-nucleotide deletion as compared with the sequence of the wild-type allele of the CCR-5 gene (fig. 2).

The data on the frequency of the $\Delta \mathrm{ccr}-5$ mutation in Kuwaiti citizens and Bedouins are presented in table 1 . No subject having the $\Delta \mathrm{ccr}-5 / \Delta \mathrm{ccr}-5$ genotype was found among the individual samples investigated in this study. The frequency of $\Delta$ ccr-5 in the Bedouins was more than 3 times higher than among the Kuwaiti citizens. The data for other ethnic groups reported in the literature are presented in table 1 for comparison.

\section{Discussion}

The $\Delta c c r-5$ deletion was reported for the first time in August 1996 [9]. Within a few months after this discovery, it was established that homozygous carriers of the mutation were absent among HIV-infected individuals $[10,17,19]$. Thus, it was concluded that homozygosity for $\Delta \mathrm{ccr}-5$ confers resistance to HIV-1 infection. The resistance is profound, though not absolute and 1 case of HIV-1 infection in a $\Delta$ ccr-5 homozygote has recently been reported in Australia [11]. The data on the protective significance of heterozygosity for $\Delta \mathrm{ccr}-5$ are controversial. On the one hand, it appears to postpone the progression of asymptomatic HIV infection to AIDS [10, 17, $20,21]$. On the other hand, at least in one group of AIDS patients (Danish cohort of HIV-1-positive male homosexuals), the survival of the $\Delta \mathrm{ccr}-5$ heterozygotes was significantly shortened [22].

One of the interesting facts reported in the first publication on $\Delta \mathrm{ccr}-5$ was the absence of carriers of the mutation outside Europe and North America. About several hundred nonEuropeans, none of them Arabs, were tested before our study, and no single individual positive for $\Delta \mathrm{ccr}-5$, even a heterozygote, was found $[9,10,17]$.

One of the explanations for that was the relatively small number of individuals of each ethnic group tested and the nonrepresentation 
of many large ethnic groups in the first studies. To close one such gap in the knowledge of ethnic distribution of $\Delta \mathrm{ccr}-5$ deletion, we undertook a survey of $\Delta \mathrm{ccr}-5$ in Arabs residing in Kuwait. We have shown here that the $\Delta$ ccr-5 deletion is not confined to populations of European descent. It is present in indigenous Arab populations of the Middle East, though its allelic frequency in Arabs is significantly lower than in Europeans.

There are two possible explanations for the origin of $\Delta \mathrm{ccr}-5$ in the Gulf Arab populations. First, the $\Delta \mathrm{ccr}-5$ deletion in Europeans and Arabs arose independently. This seems to be highly unlikely because there are no features in the genomic sequence of the wild-type CCR-5 gene suggestive of an increased probability of a specific deletion in the region of the gene where $\Delta$ ccr-5 is actually located. The alternative and more plausible explanation implies a relatively recent gene flow from Caucasians into indigenous Gulf Arab populations. Importantly, this hypothesis is testable by the identification and comparison of haplotypes (defined by polymorphisms in the genomic regions flanking the CCR-5 gene) associated with the $\Delta$ ccr-5-positive chromosomes in Europeans and Arabs.

Another interesting question related to the origin of the $\Delta \mathrm{ccr}-5$ is its timing. The mutation is clearly much more common in Europeans [9, 10], including East Europeans [23], which suggests that the mutation originates in ancient populations of Europe.

The much higher frequency of $\Delta \mathrm{ccr}-5$ in the Bedouins residing in Kuwait than in the Kuwaiti nationals deserves attention. The Bedouins belong to different tribes which are highly consanguineous groups, and it is possible that the frequency of $\Delta \mathrm{ccr}-5$ in some of the tribes can be quite high due to a 'founder' effect. Unfortunately, the information on the tribal origin of the $\Delta$ ccr-5-positive Bedouins identified in our study was not available. De- spite the difficulties in collecting samples and suitable information, an attempt to identify a hypothetical ' $\Delta c c r-5$ positive' among the Bedouin tribes seems worth pursuing.

After we had found $\Delta \mathrm{ccr}-5$ in the Arabs and some other non-Europeans, and reported these findings $[12,13]$, similar observations were reported by Martinson et al. [18]. These authors tested Arabs (241 Saudis and $34 \mathrm{Ye}$ menis) among other ethnic groups. The frequency of $\Delta$ ccr-5 in the Saudis was similar to what we had found for our Bedouin sample. None of the Yemenis was positive for $\Delta \mathrm{ccr}-5$, though the size of the sample was too small to draw any conclusion. It has to be mentioned that our latest data show that $\Delta \mathrm{ccr}-5$ is present in Arabs from the Eastern Mediterranean (Egyptians, Syrians) and in Iranians. Moreover, the frequency of the mutations in Iranians seems to be higher than that in Arabs [Voevodin et al., unpubl. data].

In conclusion, the $\Delta$ ccr-5 mutation is definitely present in Arabs, but it is too rare to significantly influence the pace of HIV-1 spreading in the Arab world. At the same time, it is possible that the frequency of the $\Delta$ ccr-5 mutation is much higher in some Arabic tribes. In a broader context, knowledge of the distribution of $\Delta \mathrm{ccr}-5$ mutation allows better global and regional modeling of the HIV-1 epidemic. The CCR-5 molecule is also a very promising target for new anti-HIV/ AIDS therapeutic and preventive interventions which, in some cases, have to be tailored according to the $\Delta \mathrm{ccr}-5$ status of the individuals.

\section{Acknowledgment}

This work was supported by grant MDI 294 from the Research Administration, Kuwait University awarded to A.V. and E.S. The authors are thankful to Mr. Abdul Aziz Al-Bisher and Miss Samia Al-Hamdan (Central Blood Bank, Kuwait) for providing blood samples from the donors. 


\section{References}

1 Detels R, Liu Z, Hennessey K, Kan J, Visscher BR, Taylor JM, Hoover DR, Rinaldo CR Jr, Phair JP, Saah AJ, Giorgi JV: Resistance to HIV-1 infection. Multicenter AIDS Cohort Study. J Acquir Immune Defic Syndr 1994;7:1263-1269.

2 Paxton WA, Martin SR, Tse D, O'Brien TR, Skurnick J, VanDevanter NL, Padian N, Braun JF, Kotler DP, Wolinsky SM, Koup RA: Relative resistance to HIV-1 infection of CD4 lymphocytes from persons who remain uninfected despite multiple high-risk sexual exposure. Nat Med 1996;2:412-417.

3 Alkhatib G, Combadiere C, Broder CC, Feng Y, Kennedy PE, Murphy PM, Berger EA: CC CKR5: A RANTES, MIP-1alpha, MIP-1beta receptor as a fusion cofactor for macrophage-tropic HIV-1. Science 1996;272:1955-1958

4 Choe H, Farzan M, Sun Y, Sullivan N, Rollins B, Ponath PD, Wu L, Mackay CR, LaRosa G, Newman W, Gerard N, Gerard C, Sodroski J: The beta-chemokine receptors CCR 3 and CCR 5 facilitate infection by primary HIV-1 isolates. Cell 1996;85:1135-1148.

5 Deng H, Liu R, Ellmeier W, Choe S, Unutmaz D, Burkhart M, Di Marzio P, Marmon S, Sutton RE, Hill CM, Davis CB, Peiper SC, Schall TJ, Littman DR, Landau NR: Identification of a major co-receptor for primary isolates of HIV-1. Nature 1996;381:661-666.

6 Dragic T, Litwin V, Allaway GP, Martin SR, Huang Y, Nagashima KA, Cayanan C, Maddon PJ, Koup RA, Moore JP, Paxton WA: HIV-1 entry into CD4+ cells is mediated by the chemokine receptor CC-CKR-5. Nature 1996;381:667-673.

7 Doranz BJ, Rucker J, Yi Y, Smyth RJ, Samson M, Peiper SC, Parmentier M, Collman RG, Doms RW: A dual-tropic primary HIV-1 isolate that uses fusin and the beta-chemokine receptors CKR-5, CKR-3, and CKR-2b as fusion cofactors. Cell 1996;85:1149-1158.
8 Feng Y, Broder CC, Kennedy PE, Berger EA: HIV-1 entry cofactor: Functional cDNA cloning of a seven-transmembrane, $\mathrm{G}$ protein-coupled receptor. Science 1996;272: 872-877.

9 Liu R, Paxton WA, Choe H, Ceradini D, Martin SR, Horuk R, MacDonald ME, Stuhlmann H, Koup RA, Landau NR: Homozygous defect in HIV-1 coreceptor accounts for resistance of some multiple-exposed individuals to HIV-1 infection. Cell 1996;86:367-377.

10 Samson M, Libert F, Doranz B, Farber C, Saragosti S, Parmentier M: Resistance to HIV-1 infection in Caucasian individuals bearing mutant alleles of the CCR-5 chemokine receptor gene. Nature 1996;386: 722-725.

11 Biti R, Ffrench R, Young J, Bennetts B, Stewart G, Liang T: HIV-1 infection in an individual homozygous for the CCR5 deletion allele. Nat Med 1997;3:252-253.

12 Voevodin A: Genetic resistance to HIV-1 due to the deletion in the CCR-5 chemokine receptor gene: Frequency in Kuwait and some other countries. Proceedings of the Fifth Kuwait International Conference on AIDS, March 1997, in press.

13 Voevodin A, Samilchuk E, Dashti S: The genetic resistance to human immunodeficiency virus type 1 (HIV1) due to delta ccr5 mutation: Frequency in Arabs and East Europeans (abstract). Health Science Poster Day, Faculty of Medicine, Kuwait University 1997, p 67.

14 Walsh P, Metzger D, Higuchi R: Chelex 100 as a medium for simple extraction of DNA for PCR-based typing from forensic material. Biotechniques 1991;10:506-513.

15 Kwok S, Higuchi R: Avoiding false positives with PCR. Nature 1989; 339:237-238.

16 Samson M, Labbe O, Mollereau C, Vassart G, Parmentier M: Molecular cloning and functional expression of a new human CC-chemokine receptor gene. Biochemistry 1996; $35: 3362-3367$.
17 Dean M, Carrington M, Winkler C, Huttley GA, Smith MW, Allimets R, Goedert JJ, Buchbinder SP, Vittinghoff E, Gomperts E, Donfield S, Vlahov D, Kaslow R, Saah A, Rinaldo C, Detels R, O’Brien SJ: Genetic restriction of HIB-1 infection and progression to AIDS by a deletion allele of the CKR5 structural gene. Hemophilia Growth and Development Study, Multicenter AIDS Cohort Study, Multicenter Hemophilia Cohort Study, San Francisco City Cohort, ALIVE Study. Science 1996;1856-1862.

18 Martinson JJ, Chapman NH, Rees DC, Liu YT, Clegg JB: Global distribution of the CCR5 gene 32-basepair deletion. Nat Genet 1997;16: 100-103.

19 Huang Y, Paxton WA, Wolinsky SM, Neumann AU, Zhang L, He T, Kang S, Ceradini D, Jin Z, Yazdanbakhsh K, Kunstman K, Erickson D, Dragon E, Landau NR, Phair J, Ho DD, Koup RA: The role of a mutant CCR5 allele in HIV-1 transmission and disease progression. Nat Med 1996;2:1240-1243.

20 Eugen-Olsen J, Iversen AK, Garred P, Koppelhus U, Pederson C, Benfield TL, Sorensen AM, Katzenstein T, Dickmeiss E, Gerstoft J, Skinhoj P, Svejgaard A, Nielsen JO, Hofmann B: Heterozygosity for a deletion in the CKR-5 gene leads to prolonged AIDS-free survival and slower CD4 T-cell decline in a cohort of HIV-seropositive individuals. AIDS 1997;11:305-310.

21 Michael NL, Chang G, Louie LG, Mascola JR, Dondero D, Birx DL, Sheppard HW: The role of viral phenotype and CCR-5 gene defects in HIV-1 transmission and disease progression. Nat Med 1997;3:338340.

22 Garred P, Eugen-Olsen J, Iversen AN, Benfiekd TL, Svejgaard A, Hofmann B, Copenhagen AIDS Study Group: Dual effect of CCR5 delta 32 gene deletion in HIV-1 infected patients. Lancet 1997;349:1884.

23 Voevodin A, Samilchuk E, Dashti S: The frequency of delta ccr5 mutation in Arabs, Asians and Russians. J Mol Med 1997;75,7;B179-B180. 